\title{
Rainwater Management for Sustaining Cotton Productivity in Medium Black Soil under Dry Farming Condition of Saurashtra Region
}

\author{
P. D. Vekaria*, V. D. Vora, T. J. Patel, J. T. Patel, G. R. Sharma, \\ H. R. Vadar and D. S. Hirpara \\ Main Dry Farming Research Station, Junagadh Agricultural University, \\ Targhadia (Rajkot), Gujarat, India \\ *Corresponding author
}

\section{A B S T R A C T}

Keywords

Cotton, FYM,

Kaolin, Net return,

Seed cotton yield,

Tillage, Water use

efficiency

Article Info

Accepted:

22 October 2020

Available Online:

10 November 2020
A field experiment was conducted during kharif season of 2011-12 to 2016-17 at Main Dry Farming Research Station, JAU, Targhadia to study the rainwater management for sustaining cotton productivity in medium black soil under dry farming condition. Main plot comprised of two tillage practices viz., ploughing every year up to $30 \mathrm{~cm}$ in set $\operatorname{row}\left(\mathrm{T}_{1}\right)$ and ploughing alternate year up to $30 \mathrm{~cm}$ in set row $\left(\mathrm{T}_{2}\right)$ and sub plot of five management practices viz., FYM @ 10 t/ha + kaolin@4\% spray $\left(\mathrm{M}_{1}\right)$, FYM @ 10 t/ha + guar gum @ $0.3 \%$ spray $\left(\mathrm{M}_{2}\right)$, gypsum@ 1 t/ha + kaolin @ 4\% spray $\left(\mathrm{M}_{3}\right)$, gypsum@1t/ha + guar gum @ 0.3\% spray $\left(\mathrm{M}_{4}\right)$ and control $\left(\mathrm{M}_{5}\right)$ was evaluated in split plot design with four replications. On the basis of six year pooled results, significantly higher seed cotton and stalk yield was obtained under application of FYM @ 10 t/ha + kaolin@ @\% spray $\left(\mathrm{M}_{1}\right)$ and it was remained at par with the application of FYM @ 10 t/ha + guar gum @ $0.3 \%$ spray $\left(\mathrm{M}_{2}\right)$ in management practices. Whereas individual effect of tillage practices and interaction effect of tillage and management practices on seed cotton yield and stalk yield were found non-significant. Maximum rain water and crop water use efficiency as well as net returns with B:C ratio were recorded in ploughing every year up to $30 \mathrm{~cm}$ in set row $\left(\mathrm{T}_{1}\right)$ and application of FYM @ $10 \mathrm{t} / \mathrm{ha}+\operatorname{kaolin} 4 \% \operatorname{spray}\left(\mathrm{M}_{1}\right)$ under tillage and management practices, respectively.

\section{Introduction}

Cotton is one of the most important fiber crops of India and play important role in economy. Due to its importance in agricultural as well as industrial economy, it is also called as "white gold". Cotton is grown mainly for its fiber, which are used in manufacturing of cloth for mankind. The oil content in the cotton seed ranges from 15 to
$25 \%$ depending on the varieties. Cotton seed cake after extraction of oil is good organic manure and contains about $6 \% \mathrm{~N}, 3 \% \mathrm{P}_{2} \mathrm{O}_{5}$ and $2 \% \mathrm{~K}_{2} \mathrm{O}$. Cotton seed cake and cotton seed are good concentrated feed for cattle. In Saurashtra region, cotton is the second most important crop after groundnut. Area under cotton cultivation in Gujarat is 26.26 lakh ha and production was 101 lakh bales during 2017-18 (Anon., 2019). Saurashtra account 65 
$\%$ area of the state and contribute $68 \%$ in the total production of the state. Low and unstable crop yields are common phenomena in dry farming area due to low, erratic and uneven distribution of rainfall. Soil-related constraints that exacerbate drought stress include crusting and compaction, low water infiltration rate, low water retention capacity, high surface runoff, and high losses due to soil evaporation (Lal, 2008).

Organic matter content is low due to high temperature and low rainfall. Soil cracking is common phenomenon in medium black soil due to which moisture loss is quit high and ultimately affect the crop production drastically. Application of FYM increases the organic matter in soil which helps in moisture retention. Use of anti-transpirants like kaolin helps plants during water stress condition by maintaining stomatal activity. Moisture conservation practices of FYM + organic mulch + kaolin spray $(6 \%)$ recorded significantly higher seed yield of Indian mustard and lentil with water use efficiency over the control (Singh and Rana, 2006). Keeping these facts and views, a field experiment was undertaken to find out suitable tillage with management practices for sustaining cotton productivity in medium black soil under dry farming condition of Saurashtra region.

\section{Materials and Methods}

A field experiments was conducted on medium black soil at Main Dry Farming Research Station, Junagadh Agricultural University, Targhadia (Rajkot) during kharif season of 2011-12 to 2016-17. The soil of the experimental site is clayey in texture, having $\mathrm{pH} 7.82$, organic carbon 0.541 and EC 0.24 mmhos/cm. Soils at $0-30 \mathrm{~cm}$ depth are low in nitrogen, low in available phosphorus (16.3 $\mathrm{kg} / \mathrm{ha}$ ) and higher in available potassium (346 $\mathrm{kg} / \mathrm{ha}$ ). The experiment was laid out in split- plot design with four replications. Main plot comprised of two tillage practices viz., ploughing every year up to $30 \mathrm{~cm}$ in set $\operatorname{row}\left(\mathrm{T}_{1}\right)$ and ploughing alternate year up to 30 $\mathrm{cm}$ in set row $\left(\mathrm{T}_{2}\right)$ and sub plot of five management practices viz., FYM @ 10 t/ha + kaolin@4\% spray $\left(\mathrm{M}_{1}\right)$, FYM @10 t/ha + guargum@0.3\% spray $\left(\mathrm{M}_{2}\right)$, gypsum@1 $\mathrm{t} / \mathrm{ha}+$ kaolin @ 4\% spray $\left(\mathrm{M}_{3}\right)$, gypsum@1t/ha + guar gum @ $0.3 \%$ spray $\left(\mathrm{M}_{4}\right)$ and control $\left(\mathrm{M}_{5}\right)$ was evaluated. Spay of kaolin and gaur gum was done at critical stage during dry spell. Gross plot and net plot size was $5.0 \mathrm{~m} \mathrm{x} 4.8 \mathrm{~m}$ and $3.15 \mathrm{~m} \mathrm{x} 2.4 \mathrm{~m}$, respectively. Bt. Cotton (G. Cot. Hy-8)was sown at onset of monsoon every year with $120 \times 45 \mathrm{~cm}$ spacing. The crop was fertilized with 80:00:00 kg NPK/ha.

The total rainfall received during the crop season (June to November) was 1044.3, $404.50,1101.4,483.1,587.2$ and $425.1 \mathrm{~mm}$ in $33,21,40,22,25$ and 27 rainy days in the year of 2011, 2012, 2013, 2014, 2015 and 2016, respectively. Productivity in terms of seed cotton and stalk yield were pooled over six years. Rain and crop water-use efficiency (WUE) was worked out by dividing the seed cotton yield by effective rainfall and $\mathrm{ET}_{\mathrm{c}}$, respectively. Economics of different treatments was worked out on the basis of pooled results of seed cotton and stalk yield of cotton in terms of gross and net returns $\mathrm{Rs} . /$ ha and $\mathrm{B}: \mathrm{C}$ ratio considering the prevailing market price of produce and cost of cultivation.

\section{Results and Discussion}

\section{Productivity}

\section{Effect of tillage practices $(T)$}

Seed cotton and stalk yield of cotton was not affected significantly due to tillage practices (Table 1). 
Table.1 Productivity, water use efficiency and economics of cotton as affected by tillage and management practices (Pooled result of six years)

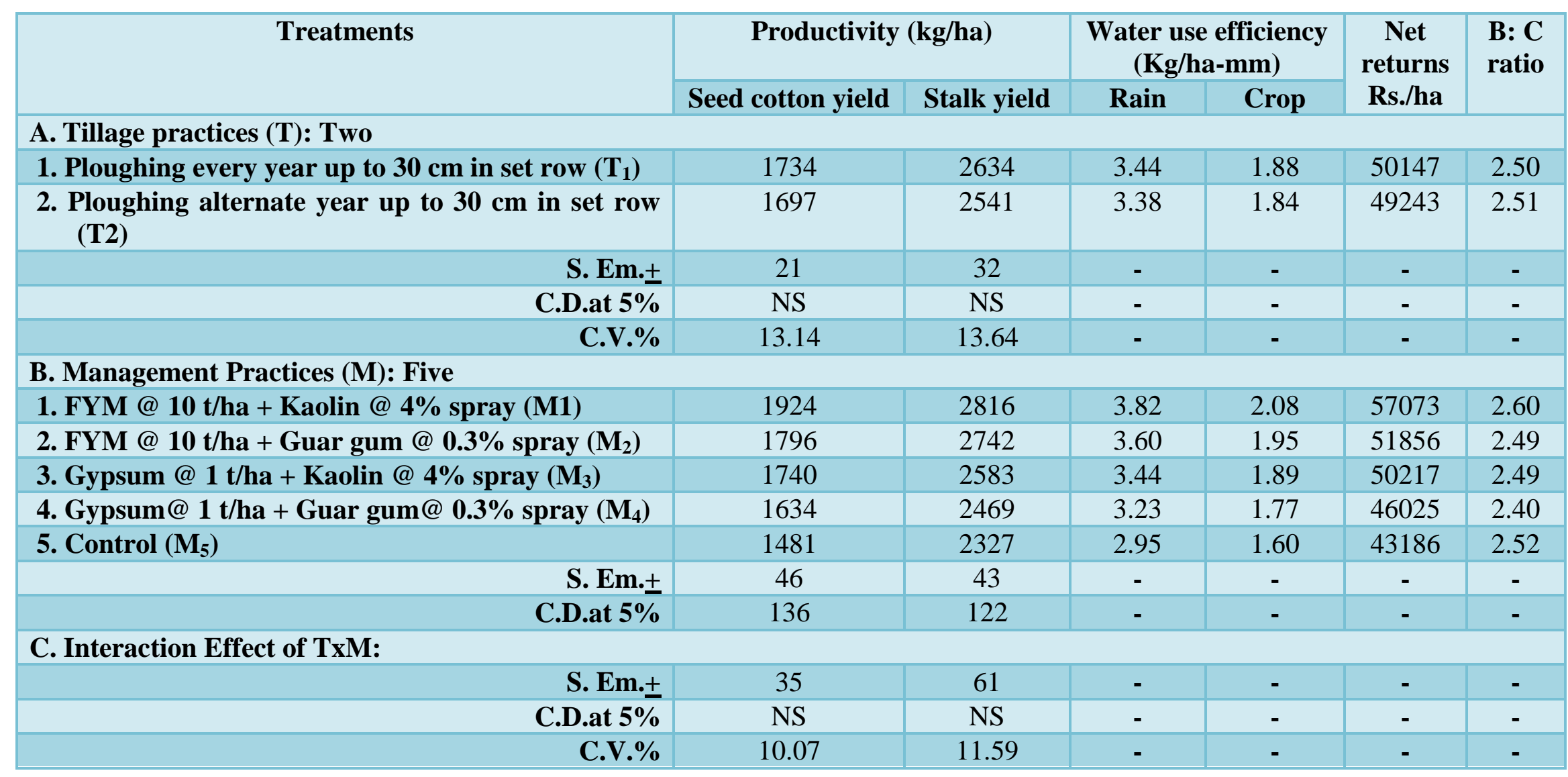


However, on the basis of pooled results of six years, higher seed cotton (1734 kg/ha) and stalk yield ( $2634 \mathrm{~kg} / \mathrm{ha})$ were recorded under ploughing every year up to $30 \mathrm{~cm}$ in set row $\left(\mathrm{T}_{1}\right)$. A similar result was observed by Patel et al., (2013) in cotton and Sutaria et al., (2010) and Vekaria et al., (2020)in groundnut.

\section{Effect of management practices (M)}

The seed cotton and stalk yield was significantly affected due to different management practices (Table 1).Significantly higher seed cotton yield (1924 kg/ha) and stalk yield $(2816 \mathrm{~kg} / \mathrm{ha})$ was obtained under application of FYM @ 10 t/ha + kaolin@4\% spray $\left(\mathrm{M}_{1}\right)$ as compared to control $\left(\mathrm{M}_{5}\right)$ in pooled results, but it was remained at par with FYM @10 t/ha + guar gum @ $0.3 \%$ spray $\left(\mathrm{M}_{2}\right)$. The magnitude of increase in seed cotton yield under application of FYM @ 10 t/ha + kaolin@4\% spray $\left(\mathrm{M}_{1}\right)$ and FYM @10 t/ha + guar gum @ $0.3 \%$ spray $\left(\mathrm{M}_{2}\right)$ was in order of 29.91 and 21.27 per cent over control $\left(\mathrm{M}_{5}\right)$, respectively. These results confirm the finding of Singh and Rana (2006) and Vekaria et al., (2020).

Interaction effect of tillage and management practices ( $\mathrm{T}$ X M)

Interaction effect of tillage and management practices ( $\mathrm{T}$ X M) on seed cotton as well as on stalk yield was found non-significant.

\section{Rain and crop water use efficiency}

On the basis of six year pooled results (Table 1), maximum rain water use efficiency (3.44 $\mathrm{kg} / \mathrm{ha}-\mathrm{mm}$ ) and crop water use efficiency $(1.88 \mathrm{~kg} / \mathrm{ha}-\mathrm{mm})$ was recorded with ploughing carried out every year up to $30 \mathrm{~cm}$ in set row $\left(T_{1}\right)$ in tillage practices. Among management practices, maximum rain water use efficiency $(3.82 \mathrm{~kg} / \mathrm{ha}-\mathrm{mm})$ and crop water use efficiency $(2.08 \mathrm{~kg} / \mathrm{ha}-\mathrm{mm})$ was recorded with application of FYM @ 10 t/ha + kaolin@4\% spray $\left(\mathrm{M}_{1}\right)$.Similar results of management practices on water use efficiency were reported byKaushik and Gautam (1994), Raskar and Bhoi (2003) and Vekaria et al., (2020).

\section{Economics}

Ploughing carried out every year up to $30 \mathrm{~cm}$ in set row gave the maximum net return of Rs.50147/ha with B: C ratio of 2.51under tillage practices. While in management practices, application of FYM @ 10 t/ha and kaolin @ 4\% spray (M1) followed by application of FYM @ 10 t/ha and guar gum @ $0.3 \%$ spray $\left(\mathrm{M}_{2}\right)$ gave the maximum net returns in terms of Rs.57073 and 51856/ha with B: C ratio of 2.60 and 2.49 , respectively as compared to rest of treatments. Singh et al., (1997) and Vekaria et al., (2020) was also observed the similar results.

It is concluded that application of FYM @ 10 t/ha and kaolin @ $4 \%$ spray at dry spell was found better for obtaining higher productivity of cotton and net returns with $\mathrm{B}$ : $\mathrm{C}$ ratio as well as maximum rain and crop water use efficiency under dry farming condition of Saurashtra region of Gujarat.

\section{References}

Anonymous 2019.District-wise area, production and yield of important food \&non-food crops in Gujarat state. Year: 2015-16, 2016-17 and 2017-18. Directorate of Agriculture, Gujarat state, Gandhinagar. Pp: 18.

Kaushik, S. K and Gautam, R. C. 1994. Response of rainfed pearl millet (Pennisetum glaucum) to water harvesting, moisture conservation and plant population in light soil. Indian Journal of Agricultural Science, 64(12): 858-860. 
Lal, R. 2008. Managing soil water to improve rainfed agriculture in India. Journal of Sustainable Agriculture, 32(1): 51-75

Patel, J. G., Patel, D. D.and Patel, D. K. 2013. Influence of depth of tillage and land configuration on growth, yield and economics of cotton (G. Cot. Hy.12). AGRES - An International e-Journal, 2 (1):28-33.

Raskar, B. S. andBhoi, P. G. 2003. Response of summer groundnut (Arachis hypogaea L.) to irrigation regimes and evapo-transpiration suppressant. Indian Journal of Agricultural Sciences, 73(2):82-85.

Singh, S.,Kaushik, S. K and Gautam, R. C. 1997. Effect of tillage and moisture conservation practices on productivity, water use and water use efficiency of pearl millet (Pennisetum glaucum) on light soil under dryland condition. Indian Journal of Agricultural Science,
67(6): 232-236.

Singh, T. and Rana, K.S. 2006.Effect of moisture conservation and fertility on Indian mustard (Brassica juncea) and lentil (Lens culinaris) intercropping system under rainfed conditions. Indian Journal of Agronomy 51 (4): 267-270.

Sutaria, G. S., Ramdevputra, M. V.,Akbari, K. N.,Vora,V. D. and Padmani,D. R. 2010, Effect of tillage and nutrient management on yield of groundnut and soil fertility. Legume Research,33(2): 131-133.

Vekaria, P.D., Vora, V. D.,Patel, T. J.,Patel, J. T.,Sharma, G. R.,Vadar,H. R. and Hirpara, D. S. 2020. Rainwater management for sustaining groundnut productivity under dryfarming conditions. International Journal of Current Microbiology of Applied Sciences, 9(1): 2033-2036.

\section{How to cite this article:}

Vekaria, P. D., V. D. Vora, T. J. Patel, J. T. Patel, G. R. Sharma, H. R. Vadar and Hirpara, D. S. 2020. Rainwater Management for Sustaining Cotton Productivity in Medium Black Soil under Dry Farming Condition of Saurashtra Region. Int.J.Curr.Microbiol.App.Sci. 9(11): 31813185. doi: https://doi.org/10.20546/ijcmas.2020.911.383 